\title{
Author Correction: Clearance of HIV infection by selective elimination of host cells capable of producing HIV
}

\author{
Min Li, Wei Liu, Tonya Bauch, Edward A. Graviss, Roberto C. Arduino, Jason T. Kimata, Min Chen \& Jin Wang
}

Correction to: Nature Communications https://doi.org/10.1038/s41467-020-17753-w, published online 13 August 2020.

The original version of this Article contained errors in the labelling of the $y$-axis scales in Figs. 3e-g and 4a. In Fig. 3e, the $y$-axis scale was incorrectly labelled from ' $10^{2}$ ' to ' $10^{9}$ ', rather than the correct ' $10^{\circ}$ ' to ' $10^{6}$. In Fig. 3f, the $y$-axis scale was incorrectly labelled from ' $10^{2}$ ' to ' $10^{7}$ ' in the left panel and from ' $10^{2}$ ' to ' $10^{8}$ ' in the right panel, rather than the correct ' $10^{0}$ ' to ' $10^{4}$ '. In Fig. $3 \mathrm{~g}$, the $y$-axis scale

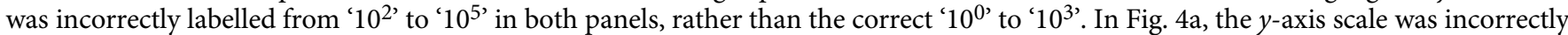
labelled from ' $10^{0}$ ' to ' $10^{9 \text { ' }}$ in the right panel, rather than the correct ' $10^{0}$ ' to ' $10^{6}$. These errors have been corrected in both the PDF and HTML versions of the Article.

Published online: 02 December 2020

Open Access This article is licensed under a Creative Commons Attribution 4.0 International License, which permits use, sharing, adaptation, distribution and reproduction in any medium or format, as long as you give appropriate credit to the original author(s) and the source, provide a link to the Creative Commons license, and indicate if changes were made. The images or other third party material in this article are included in the article's Creative Commons license, unless indicated otherwise in a credit line to the material. If material is not included in the article's Creative Commons license and your intended use is not permitted by statutory regulation or exceeds the permitted use, you will need to obtain permission directly from the copyright holder. To view a copy of this license, visit http://creativecommons.org/licenses/by/4.0/.
}

(C) The Author(s) 2020 